\title{
ANALYSIS OF THE BRAZILIAN CRISIS: PRELIMINARY EFFECTS ON SOUTH-SOUTH COOPERATION ${ }^{1}$
}

\author{
Patricia Andrade de Oliveira Silva ${ }^{2}$ \\ Niemeyer Almeida Filho ${ }^{3}$
}

\section{Introduction}

Brazilian international cooperation can be historically characterized as a 'peaceful insertion' with a focus on commercial alliances. The international insertion of the country was developed through alliances and free trade agreements and/or integration through blocs of states, sometimes led by developed countries (Guimarães 2013, Pecequilo 2012). Brazil has also maintained a long-standing pragmatic alignment with the United States, referred to as North-South, or vertical cooperation. In addition, historic patterns of international cooperation confirm that Brazil is a country with significant participation in negotiations, international assemblies and in the UN Security Council since the Second World War. These activities were intensified throughout the 2000's.

When United Nations launched its 1994 Development Agenda, it represented an expansion of the UN approach to International Cooperation and Development (ICD). According to Milani (2OI2), a central characteristic of this type of cooperation is that it seeks development based on solidarity in efforts to face the dilemmas and inequalities generated by capitalism. This approach to ICD came to be characterized as South-South Cooperation

\footnotetext{
I The authors are thankful for the collaboration of: Mariana Balboni, coordinator at Social Protection Org, Fábio Veras Soares and Rafael Guerreiro Osório, Senior Research Coordinators of IPC-IG and Stephen Kidd, Senior Social Policy Specialist of the Development Patways.

2 Professor at University Anhembi Morumbi; PhD in Economic Development, Space and Environment by UNICAMP. E-mail: pandrade.eco@gmail.com

3 Professor at Federal University of Uberlândia (UFU); PhD in Economic Theory from UNICAMP (I994); post-doctorate by FEA-USP, Department of Economics (2009). E-mail: nafilho@ufu.br
} 
(SSC) consisting of an expansion of ICD focused on countries of the South as many of them experienced periods increasing growth and development in the past decade, thus transforming themselves into potential "donors" with the possibility to offer loans, technical assistance and various forms of foreign investments to promote regional development. (Silva and Almeida Filho 20I9).

Throughout the period following the election of former president Luís Ignácio Lula da Silva, national interests were structurally brought into conformity with ICD objectives (starting with the Zero Hunger initiative that eventually gained international recognition for its significant results in fighting hunger and poverty through social policy) and Brazil came to stand out amongst countries in similar situations. According to Chediek (20I7), the development of a partnership between the Brazilian government and the United Nations Development Program (UNDP) happened after 20I0 when bilateral and multilateral international cooperation was expanded through the Brazilian Cooperation Agency (ABC).

Fraundofer (2OI2) analyzed this partnership, particularly the centers of research excellence. The first such center was the International Policy Centre for Inclusive Growth (IPC-IG), established in 2004. According to the Centre's website $^{4}$ IPC-IG is a global forum for South-South dialogue about innovative development policies, seeking the production and dissemination of papers, policy recommendations and the exchange of best practices, establishing contact with several national and international institutions.

The Social Protection.Org platform was established in 2015, also focusing on the dissemination of knowledge in the area of social protection. According to the platform's websites, it was created following a request from the G20 Development Working Group. Its purpose is to serve as a repository of learning resources on social protection for policymakers, development practitioners and specialists, with an interest in South-South learning. Currently, the platform is composed of 3,631 members and 973 registered institutions from around the world. Brazilian institutions such as the Institute of Applied Economic Research (IPEA), the Ministry of Social Development (MDS), the National Council of Social Assistance (CNAS) are part of the platform.

These activities evidence a growing focus on ICD and SSC. Two reports of the IPEA and the Brazilian Agency for Cooperation (ABC) confirmed this focus with an analysis of investments in this area. The reports demonstrate

4 More information available at <http://www.ipc-undp.org/pt-br/>

5 More information available at <http://socialprotection.org/> 
that the amount spent by the Brazilian government on ICD was close to US\$ I. 5 billion between 2011 and 2013 applied in almost I60 countries. These resources were utilized for "the dissemination of successful Brazilian practices, training of foreign specialists and granting of scholarships in educational institutions in Brazil" (IPEA and ABC 2016, I7, author's translation).

However, since the impeachment of ex-president Dilma Rousseff in 2016, it has become increasingly clear that the current government does not prioritize ICD or SCC. The government's own plan of action ${ }^{6}$ that it presented to the public included a narrow focus on the negotiation of trade agreements (with or without Mercosur). This article analyzes preliminary changes to Brazilian activities and participation in SSC in the period after 2004 and presents future perspectives taking the current state of crisis into account. A bibliographical review is combined with an analysis of published information available about the participation of Brazilian government agents in relevant platforms and networks analysis related to socialprotection.org. Following this introduction, this article is divided into the following sections: a) SSC: Synthesis of theoretical aspects and recent evolution; b) Social Network Analysis: The case of the Socialprotection.org platform; c) Final considerations; d) References and e) Annex I.

\section{SSC: Synthesis of Theoretical Aspects and Recent Changes}

\section{Synthesis of Theoretical Aspects}

The historical evolution of successive Brazilian governments' international activities offers insights into temporal political specificities despite the country's historically consistent presence in major international activities and negotiations. According to Guimarães (2013), Brazil's geographic location, regional importance and territorial dimension are key factors in this continuous presence. Importantly, Silva and Almeida Filho (2019) highlight that since I900 the country has been working to consolidate its relations with North America through a submissive alliance with developed countries, particularly those from the North.

Pecequilo $(2012,2008)$ investigated the first movements away from these historic submissive North-focused relations that began in the I960's when the country was going through considerable internal and external changes. Additionally, it is important to highlight the early attempts at an

6 The government plan is available here: <https://www.fundacaoulysses.org.br/wp-content/ uploads/20I6/II/UMA-PONTE-PARA-O-FUTURO.pdf> 
import substitution strategy that began in Brazil in the I930's. Another key external factor that provoked substantive changes to Brazil's insertion internationally was the shifting power balance throughout and since the Cold War.

Milani (20I2) confirms that the Cold War served as an important mechanism for the institutionalization of multilateralism, elevating the importance of ICD because the 'Soviet threat' elicited an improvement to U.S international development programs. ICD aims to promote "dialogues through public policies on the basis of selectivity and training programs (...), therefore, international aid has come under the logic of cooperation and partnerships" (Milani 20I2, 2I4, author's translation).

SSC follows the expansion of ICD activities in countries of the global South, including in Brazil. According to Silva and Almeida Filho (2019), the creation of the Brazilian Cooperation Agency (ABC) in I987 had the objective of creating technical cooperation programs in several areas that brought international organizations and governments together with an explicit focus on development projects in the south.

In his commemorative book marking the $30^{\text {th }}$ anniversary of the $\mathrm{ABC}$ (published in 20I7), Chediek highlighted the fact that, "the guiding principles of SSC are included in several official United Nations documents: the respect for national sovereignty, appropriation and independence, equality, non-conditionality, non-interference in domestic affairs and mutual benefit" (Chediek 20I7, 44, author's translation). Additionally, it is necessary to reference the important contribution of a document prepared at the United Nations High Level Conference in Nairobi in 2009. According to this document (UN 2009, 4) at points IO and II, the United Nations clearly recognizes the importance of CSS:

We recognize the importance and different history and particularities of South- South cooperation, and we reaffirm our view of South-South cooperation as a manifestation of solidarity among peoples and countries of the South that contributes to their national well-being, their national and collective self-reliance and the attainment of internationally agreed development goals, including the Millennium Development Goals. South-South cooperation and its agenda have to be set by countries of the South and should continue to be guided by the principles of respect for national sovereignty, national ownership and independence, equality, nonconditionality, non-interference in domestic affairs and mutual benefit.

Milani (20I2), Hirst (20I2) and Leite, Suyama and Waisbich (20I3) 
demonstrate that following the positive results of Brazilian social policy throughout the $2000 \mathrm{~S}^{7}$, projects developed in these areas gained the attention of international managers, particularly those from Southern countries who were eager to learn about the Brazilian experience of effective strategies to reduce both poverty and inequality. Analyzing the relationship between the UN and the Brazilian government during the 2000's, Silva and Almeida Filho (20I9) report the growth of a closer relationship in the context of the UN Millennium Development Goals (MDGs), which have now been incorporated into Agenda 2030 (Sustainable Development Goals - SDGs ${ }^{8}$ ) the goal of which is to eradicate poverty in all its forms by 2030 . SSC is an important tool for achieving these goals as it gives priority to emerging (mostly southern) countries.

These same authors affirm that throughout the 2000s the Brazilian government operationalized a synchrony between internal objectives (especially the fight against extreme poverty), the UN SDGs and SSC. According to ex-foreign minister Celso Amorim (2007), this synchrony was eventually concretized in the government's desire to obtain a permanent seat at the UN Security Council. As the UN document referenced above (2009) demonstrates, the existence of CSS does not modify or compete with traditional North-South (vertical) cooperation, especially the negotiation and operationalization of bilateral and multilateral trade agreements, but rather maintains a conciliatory and sometimes even submissive role for southern countries (including Brazil) in relation to developed economies and governments.

In this sense, Brazilian official government discourse knowledge transfer and technical cooperation, focusing on sharing national practices with countries with similar challenges. According to Leite et. al. (20I4, 20), "Brazil claims to have a firsthand understanding of poverty and underdevelopment, which differentiates it from industrialised countries. The importance of the adaptation process, the recognition of local experiences and the existence of synergies between partners is also recognized".

It is possible to observe that the Brazilian government's focus on SSC grew substantively between 2004 and 2010 with the creation (in 2004) of the "General Coordination of Humanitarian Cooperation and Fight against Hunger" in the Ministry of International Relations (referred to as Itamaraty in Brazil) to coordinate international actions to alleviate poverty in other countries. These actions enhanced partnerships with United Nations agencies (with the

7 For further details, see Silva (20I7).

8 Further details about the SDGs available here: <https://www.un.org/sustainabledevelopment/ sustainable-development-goals/> 
UNDP and the Food and Agriculture Organization - FAO in particular) and were fundamental to the dissemination and exchange of experiences between Southern countries. Chediek (20I7, 57, author's translation) reported that this partnership led to:

...four main types of UNDP support for Brazilian SSC: a) institutional capacity building; b) operational support for bilateral and trilateral technical cooperation; c) research, collection and analysis of Brazilian practices and policies; and, d) facilitation of knowledge sharing and partnerships. These approaches had a central objective: maximize Brazilian potential for technical cooperation and their successful good practices and social policy.

This partnership also led to the creation of centers of research excellence including the Center of Excellence against Hunger and World Center for Sustainable Development which were developed to maximize the potential of SSC. Silva and Almeida Filho (2019) and Fraundorfer (20I2) all highlight that the first center of excellence created in 2004, the International Policy Centre for Inclusive Growth (IPC-IG) constructed various connections with relevant international agents with a focus on research and dissemination of knowledge in the area of social protection. "Since 2009, the Centre has expanded this network through their involvement in academic forum's, BRIC's think tanks seminars and the G20 working groups." (Fraundorfer 20I2, p IO4, author's translation).

This series of consecutive efforts and investments made by the Brazilian government and international organizations (particularly those of the FAO and the UNDP) to deepen SSC over the past decade were very important. They yielded mechanisms for experience sharing (particularly experiences with innovative social policy) the creation of research centers, thus elevating the importance of international insertion at a regional level.

\section{Recent Changes on SSC}

It is important to study recent Brazilian history of involvement in SSC and given the structural limits on the Brazilian fiscal regime, and the period of economic growth experienced by the Brazilian economy in the last decade, the beginning of the 2Ist century presented the possibility of a considerable expansion of social policy in Brazil (Silva 20I7, Silva and Almeida Filho 2019) and, consequently of SSC as demonstrated before. There was real and continuous appreciation of the minimum wage (with significant impacts on social security and pensions) and several poverty eradication and inequality 
reduction policies were implemented. The effects of this period of economic growth and these policies can be observed in the Brazilian indicators of poverty and inequality. Extreme poverty between 2004 and 2014 was reduced from $\mathrm{I} 6.4 \%$ to $4.7 \%$ and the Gini Index fell from 0.570 to 0.515 . Average per capita household income rose from $\mathrm{R} \$ 549.83$ to $\mathrm{R} \$ 86 \mathrm{I} .23$ during the same period. (Osório 2015).

According to Silva and Almeida Filho (2019), as of 2014 (the beginning of the second Dilma government) reforms and parliamentary amendments were already demonstrating a change in direction towards fiscal adjustment and spending containment (concurrent with a significant reduction in economic growth), a tendency that was intensified after Dilma's impeachment and, most significantly, institutionalized with the approval of EC (constitutional amendment) 95. Ulhôa and Almeida Filho (20I8) demonstrate that the main objective of EC95 was to consolidate the previous fiscal regime through the compulsory generation of a primary accounts (balance of payments) surplus.

Several researchers have warned of the negative effects of setting limits on primary expenditure on public policies, especially social policies In addition, the Synthesis of Social Indicators of IBGE (2OI7) shows that the drop in health and education expenditures was $3.1 \%$ in 2017 , after discounting inflation.Another important measure that indicates how social policy is impacted by this kind of fiscal adjustment is the return of the growth of poverty indicators which, according to a report that analyzed data from the Getúlio Vargas Foundation (FGV), "between 20I4 and 20I7, the number of people living below the poverty line in Brazil grew 33\%, which means 6.3 million new poor people in the country - the equivalent of almost twice the population of Uruguay"9.

Faced with this scenario of crisis, cuts to public policy expenditures and their effects that are beginning to emerge and are being made clear by the poverty indicators cited above, the focus of this article, SSC will certainly not be exempt from cuts. There is little direct, detailed information on either ICD or SSC. The most significant consequences to date have been published in reports from 2010 and 2016 through a partnership between the ABC and the IPEA that assesses the performance of Brazilian ICD.

Silva and Almeida Filho (20I9) analyzed both of these reports and demonstrated that in monetary values, ICD spending practically doubled between 2005 and 2009 , an increase from $R \$ 384.2$ million to more than

9 Article available at: <https://noticias.uol.com.br/cotidiano/ultimasnoticias/2018/09/13/mais-de-6-milhoes-cairam-abaixo-da-linha-de-pobrezadesde-20I4-aponta-fgv.htm>. 
R\$ 724 million in nominal values. According to these same authors, when divided into sub-items, spending on humanitarian assistance and technical cooperation increased from $7.53 \%$ of the total in 2005 to $25.51 \%$ in 2009 , a six-fold increase. However, the 2016 report points out that this growth loses strength between $20 \mathrm{II}$ and 20I3, with an increase from $\mathrm{R} \$ 985$ million in 20II, to approximately $\mathrm{R} \$$ I billion in $20 \mathrm{I2}$ and then a reduction to $\mathrm{R} \$ 857$ million in 2013 .

The 2016 IPEA/ABC Report explains that a South-South Cooperation Trust Fund was created. The Brazilian government's financial contribution to this fund was R\$ II.8 million between 20II and 20I3. This investment was used to fund I4 projects with the goals of sharing technology, knowledge and resources in the areas of agriculture, governance and social development.

There is a clear commitment and effort on the part of the Brazilian government throughout the last decade to operationalize successful social policies and to offer Brazilian programs and projects as examples for other countries in similar conditions. Integration with the United Nations was deepened through several centers of excellence and bi and trilateral SSC projects. As noted in the previous section, the first center of excellence in research created between the UN (through the UNDP) and the Brazilian government was the International Policy Centre for Inclusive Growth (IPCIG), which has as one of its objectives to be a global forum for South-South dialogue.

Since 20I5, the IPC-IG has hosted the socialprotection.org platform that focuses on the dissemination of knowledge in the area of social protection and South-South learning. This work has as a general hypothesis that the decrease in public spending on social policy will compromise the performance of SSC and will use the socialprotection.org platform as a case study to explore its main agents (stakeholders) and impacts on Brazilian participation in the network of other southern countries. The next section will explore the methodology used in this study, elaborate a historical mapping (which includes an analysis of the platform and interviews with external agents and current collaborators) and examine the current network of stakeholders.

\section{Social Network Analysis: The socialprotection.org Platform}

The objective of first section was to show the Brazilian government efforts to create partnerships with international organizations to disseminate the ICD and SSC. In this sense, this section will explore the creation of the first center of research excellence in 2004, the International Policy Centre for 
Inclusive Growth (IPC-IG) with focus on the socialprotection.org platform, as mentioned before.

The IPC-IG is a center built between Brazilian government partnerships with United Nations. It has been constructed various connections with relevant international agents with a focus on research and dissemination of knowledge in different areas of development. In 20I5, the IPC-IG launched the platform socialprotection.org with focus on dissemination of knowledge on social protection around the world. Using the platform we intend to analyze how the Brazilian government was (and if it still is) involved and if the current crisis affected the government participation on socialprotection.org. Searching to discover this effects the article will use a social network analysis and it divided this session in: historical network analysis and NetMap results.

\section{Historical Network Analysis}

According to the socialprotection.org website and two of its own recent annual reports (20I6 and 20I7), the platform was established through an official agreement between the IPC-IG and the Department of Foreign Affairs and Trade of Australia (DFAT) that was signed in January 20I4. That agreement created a prototype that was officially launched on I2 September 20I5 which is the United Nations Day for South-South Cooperation. The platform's mission is to be an online focal point for the repository of knowledge and sharing on social protection in the South. Institutions and individuals interested in this area can register for free online (Social Protection.org 20I6; 20I7).

For the platform itself, social protection is a concept that encompasses a range of policies and programmes designed to provide individual or family support where social vulnerability exists. Social protection thus defined seeks the inclusion and construction of human and social capital by increasing income, consumption and ensuring access to basic human rights, as well as stimulating production through the capacity development, and the securing of rights and opportunities. (Social Protection.org 2016).

Once registered on the platform, members can benefit from 4 main platform tools: a) Discover: where publications are gathered and shared by/ with members; b) Connect: the platform has several online communities subdivided into various topics related to social protection; c) Learn: virtual campus where it is possible to search for courses in social protection offered by members of the platform and, finally, d) Share: where members can add a publication, a program, an institution, an online community, events etc.

A steady and significant increase in the number of registered members and institutions is observable since the inception of the platform. Together with 
the Australian DFAT and some other institutions, the German Gesellschaft für Internationale Zusammenarbeit (GIZ) has offered steady financial support to the platform since December 20I5. In addition to understanding these funding sources, it is necessary to investigate the background that influenced the creation of the platform, which goes back to the very creation of the IPCIG and the work carried out by the research centre since 2004 .

The interview with the senior coordinators of the IPC-IG revealed that the conception of the creation of this centre predates the Lula administration, since the initial assumption was to replicate the work carried out by the IPEA on poverty studies and pro-poor growth ${ }^{\mathrm{I}}$. The IPC-IG was understood be a partnership between the Brazilian government and the UNDP to provide international scope for such research and not serve as an instrument to promote SSC.

The first IPC-IG implementation agreement was signed by the Lula government in 2004. This agreement defined that the Centre would be an integral part of the UNDP structure, observing a formal but weak institutional framework which was built over the years until 2009, when a second and definitive agreement was reached. Since 2004, the Brazilian government has collaborated by hosting the IPC-IG on one of the floors of the IPEA building, with the IPEA coordinator being housed within the Centre (at the time represented by its president, Marcelo Medeiros) and with shared IPEA technicians making up the staff of researchers and coordinators. According to the interviewees, at that time, it was very close to what IPEA is today with a strong focus on the area of quantitative studies of poverty reduction. Thus, even with the formal agreement and the professional science of the $\mathrm{ABC}$, it was not expected that the IPC-IG would become an important research centre in the area of learning in the South.

The change of the Centre's interests from an academic profile to one that could work in direct partnership with international managers began between 2005 and 2006 and occurred through two distinct processes:

I) A survey conducted by IPEA by Soares et. al. (2007) which explored and compared the impacts of the Bolsa Família Programme on inequality and poverty in Brazil with results of local programmes in Chile and Mexico. This survey was based on data from the 2004 National Household Sample Survey (PNAD) and was also published as Working Paper by the IPC-IG in English

Io Among these studies the following stand out as important: Barros et. al. (2000;2007). Ricardo Paes de Barros was the director of the Social Studies Council of the IPEA between I999 and 2002 . 
(Soares, Riba and Os"'orio 2007). This publication was widely disseminated in the international academic community through the Development Policy Review, the journal of the Overseas Development Institute (ODI) ${ }^{\mathrm{II}}$. The researcher Rachel Slater came into contact with this work and would subsequently recommend that the IPC-IG host a platform to disseminate knowledge on social protection for developing countries;

2) Between 2005 and 2006, researchers (including Stephen Kidd) from the UK Department for International Development (DFID), and its counterpart in Brazil held two meetings: a) one with the IPC-IG to carry out research and simulations of cash transfer programmes in African countries and; b) a second where DFID sought someone to articulate within the Brazilian government to initiate cooperation with African countries in the area of social protection.

According to the interviewees, relations between counterparts in African countries and IPC-IG researchers were strengthened after these meetings as the Brazilians received and accepted several invitations to present their research at international seminars, especially in Africa. In sequence, another DFID mission was organized in Brazil to organize a major social protection survey in Africa (in Kenya, Zambia and Uganda) in partnership with local researchers in order to improve monitoring and knowledge transfer. During this period, meetings were held between the ABC and DFID, where the DFID suggested that the IPC-IG should be the executing agent and facilitator of the project (including translating the documentation of the Brazilian experience). However, according to the Brazilian government this trilateral cooperation project was beyond the scope of the $A B C$ due to the need for documentation of the Brazilian experience. Instead, the joint project was managed directly by the international advisor of the Ministry of Social Development (MDS).

This initiative was of fundamental importance to the development of cash transfer programmes in Africa. This project generated other cooperation projects between Brazil and Africa including Brazil-Africa I in 2006, and then the proposal for a new Brazil-Africa II project, in 20I4. The second project included the proposal to create a platform for the dissemination of knowledge on social protection. That proposal was realized with eh creation of the socialprotection.org platform.

Importantly, one of the DFID researchers involved the negotiation of the Brazil-Africa I project, is the current founder and senior coordinator of

II More information available at: <https://www.odi.org/> 
the Development Pathways ${ }^{12}$ consultancy. He granted an interview via Skype, where he recalled some important dimensions from this period. According to the interviewee, who participated in the first years of the construction of the project indicated that at the time there was considerable international interest in learning about the Brazilian experience with the Bolsa Família program. After understanding the Brazilian social protection system better, he believed it to be a great mistake, arguing that other programs (such as our retirement system) have much greater poverty and inequality reduction effects than cash transfer programs ${ }^{13}$.

All interviewees pointed out that several conferences were held during this period and that the DFID, IPC-IG and the MDS participated in this process in Africa. However, the IPC-IG coordinator pointed out that, "the central problem for the Brazilian government in relation to international cooperation was (and is): insufficient volume of resources and available technicians." Also, the former DFID official's insistence that despite MDS promotion, the Bolsa Família was detrimental to other Brazilian social protection programmes. Finally, it was highlighted that due to internal (economic and political) conditions of the African countries themselves there were not sufficient resources or political interest for the construction of large-scale programmes of social protection.

According to the interview with IPC-IG researchers, the Brazil-Africa project was an important moment for Brazilian ICD. It was also reported that a few years later, after the first Dilma government, a retraction of the Brazilian government from SSC occurred which confirmed a break with previous international insertion strategy as resources invested in SSC were reduced relative to previous years (IPEA 20I6, ABC 20I6). During this period, MDS initiated a series of annual international seminars, with the justification that it would not be possible to meet all the international demands, so they would all be grouped into a single event.

The seminars led to a degree of dissatisfaction among international managers as they proved insufficient to effectively pass on knowledge through technical assistance. The IPC-IG received new demands for technical assistance from partners based in African countries which was subsequently carried out through a study tour at the Centre.

The IPC-IG made great strides towards direct participation in social

I2 Available at: < http://www.developmentpathways.co.uk/>

I3 According to an article published by the interviewee, (Kidd and Huda 2013) when analyzing the data of Soares et. al. (2006) the Bolsa Família and Benefício de Prestação Continuada (BPC) income transfer social programs contributed to a $5 \%$ reduction in poverty, while the retirement policies reduce poverty in $17 \%$. 
protection projects during this period. After 20 Io the organization was sought out by other international institutions including the Australia Department of Foreign Affairs and Trade (DFAT) ${ }^{\mathrm{I}}$ and the Deutsche Gesellschaft für Internationale Zusammenarbeit (GIZ) ${ }^{15}$. In the specific case of the DFAT, the IPC-IG was asked to create a platform for the dissemination of content on social protection. The so-called 'Social Protection Gateway' was being developed as a prototype, but there was no follow-up at the time.

A recommendation ${ }^{16}$ to create a platform focused on social protection and knowledge sharing was made at the 2011 G20 Development Group meeting. This recommendation would operationalize an integral part of the future objectives of the organization's "Pillar 6" (Growth with Resilience) and "Pillar 9" (Knowledge Sharing). According to the meeting's report, construction of this platform should be carried out by and/or in cooperation with international organizations that make use of pre-existing tools. Interviewees pointed out that the Brazilian government does not recognize the G2O Development Group as a social forum, so no Brazilian institution participates in its working groups focused on social issues.

The IPC-IG accumulated experience from the Social Protection Gateway tool and in 2013 the DFAT (aware of the recommendation of the G2O Development Group) made a proposal to revive the platform through new funding. DFAT's interest was due to several interrelated factors including growing demands from countries where Australia financed investments in social protection, a desire to highlight the country as an important contributor to the construction of social protection research globally, efforts to maintain the credibility and ability of the country to influence debates in this area, especially in the Pacific region and finally, Australia was scheduled to assume the presidency of the G20 Development Group in 20I4.

It is also important to highlight the withdrawal of the MDS from these activities during this period as it focused on projects with conditionality models (for example, the Bolsa Família Program) for Africa with the World Bank and its Community of Practices $(\mathrm{CoP})^{17}$. Another key element in 2013

I4 More information available at: <https://dfat.gov.au/pages/default.aspx>

I5 More information available at: <https://www.giz.de/en/html/index.html>

I6 Report of the $201 \mathrm{II} 20$ Development Group meeting in France: <https://reliefweb.int/sites/ reliefweb.int/files/resources/20IIIO28_REPORT_WG_DEVELOPMENT_vANG\%5BI\%5D. pdf>

I7 Communities of Practice (CoP) is an initiative undertaken by the World Bank and UNDP since 2002 with the aim of contributing to development in the Middle East and North Africa. It is an opportunity for policy makers to share experiences and knowledge. (JOHNSON and KHALID, 2005). 
was the hosting of one of the meetings of the Social Protection Inter-Agency Cooperation Board (SPIAC-B) $)^{18}$, where two events stood out ${ }^{\mathrm{t} 9}$ : a) The IPCIG formally presented the proposal to create the social protection platform together with the UNDP's Poverty Practice and in consultation with the World Bank and the ILO and; b) the United Nations Children's Fund (UNICEF) and the FAO proposed a project to evaluate cash transfer programmes in 8 African countries which led to IPC-IG participation in the coordination meetings for these evaluations since 2008. A specific CoP for African countries was also suggested at this meeting with the World Bank itself suggesting that the event be held in the Brazilian city of Fortaleza. The IPC-IG was invited to participate in this CoP which was held in March 20I4.

The Fortaleza CoP was a key event for the socialprotection.org platform as the formal proposal for its creation was made in Fortaleza. Interviewees indicated that simultaneously, DFID Brazil created a new division on social protection and food security in order to carry out a new round of projects such as those carried out by Brazil-Africa, where the IPC-IG would deal with the social protection dimension. Thus, the Centre organized a meeting with the $\mathrm{ABC}$, the MDS and African representatives to systematize this demand despite the lack of support from Brazilian institutions. In order not to create problems with the ABC, the Research Centre uses the term South-South Learning and not South-South Cooperation, as the ABC has its own definition of what $\mathrm{SSC}^{20}$ should be.

Since the Australian government assumed the presidency of the $\mathrm{G}_{2} \mathrm{O}$ Development Group in 20I4, there has been a substantial boost to the growth of socialprotection.org which now also included content on social protection and experiences sharing between middle-income and low-income countries. Thus, through the indication of Rachel Slate (who had become aware of the work developed at the IPC-IG), the Centre was indicated as a possible host for the platform since it was essential that it be developed by an institution based in the South and that maintained sufficient knowledge on the subject.

I8 SPIAC-B is an inter-agency organization composed of several representatives of international organizations and bilateral institutions, with the purpose of improving global coordination in the defense of social protection and coordination of international cooperation projects in this area. Further information: <https://www.ilo.org/newyork/issues-at-work/social-protection/ social-protection-inter-agency-cooperation-board/lang--en/index.htm>

I9 2013 SPIAC-B meeting report available at: <https://www.ilo.org/wcmsp5/groups/public/--dgreports/---nylo/documents/genericdocument/wcms_231369.pdf>

20 The work of Silva e Almeida Filho (20I9) explores the definition of SSC and it follows the principles defended by the UN (2009) in Nairobi, which are also reconfirmed by most international organizations. Thus, it is difficult to understand what the definitional difference is for $\mathrm{ABC}$. 
The socialprotection.org platform was established in 2015 . Interviewees highlighted the fact that the platform is not directly connected to the Brazilian government. Rather, the initiative for the building of the platform was an indirect result of Brazil's emphasis on SSC, including the creation of the IPCIG, which became the platform's host. Table I systematizes the historical mapping of the main processes, including the indirect but important support that came from ICD and SSC practiced by the Brazilian government throughout the period under analysis.

Despite the platform being totally globalized and integrating experience and knowledge from members and institutions from around the world the indirect importance of the Brazilian government in the platform is clear when the history of its creation is considered. The next section will review the main institutions that currently use socialprotection.org and analyze the Brazilian government's participation, mapping its involvement using NetMap.

\section{Table 1. Historical mapping of the creation of the socialprotection.org platform}

\begin{tabular}{|c|c|c|}
\hline Period & Process & Participating institutions \\
\hline $2005-2006$ & $\begin{array}{l}\text { Publication of the work } \\
\text { of Soares et. al. }(2007) \text { on } \\
\text { the comparative impacts } \\
\text { of the Bolsa Família } \\
\text { Programme on inequality } \\
\text { and poverty in Brazil with } \\
\text { similar programs in Chile } \\
\text { and Mexico }\end{array}$ & IPEA and IPC-IG \\
\hline $2005-2006$ & $\begin{array}{l}\text { Growth in DFID's interest } \\
\text { in conducting social } \\
\text { protection studies and } \\
\text { programmes in Africa }\end{array}$ & $\begin{array}{l}\text { IPC-IG, DFID - Brazilian } \\
\text { institutions }\end{array}$ \\
\hline 2006 & Project Brazil-Africa I & $\begin{array}{l}\begin{array}{l}\text { IPC-IG, DFID, MDS, } \\
\text { among others }\end{array} \\
\end{array}$ \\
\hline 2006-2010 & $\begin{array}{l}\text { Seminars and various } \\
\text { meetings related to the } \\
\text { Brazil-Africa Project }\end{array}$ & $\begin{array}{l}\text { IPC-IG, DFID, MDS, } \\
\text { among others }\end{array}$ \\
\hline 2010 & $\begin{array}{l}\text { Creation of the Social } \\
\begin{array}{l}\text { Protection } \\
\text { prototype }\end{array}\end{array}$ & DFAT e IPC-IG \\
\hline
\end{tabular}




\begin{tabular}{|c|c|c|}
\hline $20 I I$ & $\begin{array}{l}\text { Demand from the G20 } \\
\text { Development Group for } \\
\text { the creation of a platform } \\
\text { for sharing content on } \\
\text { social protection aimed at } \\
\text { exchanging experiences } \\
\text { between middle-income } \\
\text { and low-income countries }\end{array}$ & Various \\
\hline 2013 & $\begin{array}{l}\text { SPIAC-B meeting where } \\
\text { the IPC-IG presented } \\
\text { the socialprotection.org } \\
\text { platform and UNICEF } \\
\text { and FAO proposed a } \\
\text { project to evaluate cash } \\
\text { transfer programmes in } \\
8 \text { African countries, and a } \\
\text { specific CoP for Africa in } \\
\text { Fortaleza }\end{array}$ & Various \\
\hline 2014 & CoP in Fortaleza & Various \\
\hline 2014 & $\begin{array}{l}\text { DFID Brazil proposes } \\
\text { a new round of Brazil- } \\
\text { Africa II projects through } \\
\text { its division for social } \\
\text { protection and food } \\
\text { security }\end{array}$ & $\begin{array}{l}\text { DFID-BR; IPC-IG; MDS, } \\
\text { ABC, among others }\end{array}$ \\
\hline 2014 & $\begin{array}{l}\text { Australian government } \\
\text { assumes Presidency of the } \\
\text { G2o Development Group, } \\
\text { which then appointed the } \\
\text { IPC-IG as the developer } \\
\text { and host of an online } \\
\text { platform for social } \\
\text { protection }\end{array}$ & $\begin{array}{l}\text { Various (no Brazilian } \\
\text { institutions) }\end{array}$ \\
\hline 2015 & $\begin{array}{l}\text { Creation of the } \\
\text { socialprotection.org } \\
\text { platform }\end{array}$ & $\begin{array}{l}\text { IPC-IG; DFAT; GIZ, } \\
\text { among others }\end{array}$ \\
\hline
\end{tabular}

Source: Field research

\section{NetMap: Results}

A case study can be understood as a methodology in which the choice of an object of study is defined by an interest in individual cases (Silva 
20I5). Thus, it is possible to understand and apply this approach to analysis of networks since its main objectives are also to understand the various relationships that exist between the agents that make up a community.

Research based on the use of case studies was popularized in the I970s and has grown continuously throughout the last decades. Many authors have applied this methodology to study networks in a wide diversity of contexts. The representation of a network can be made in several ways. One important manner to describe and study a network is an analysis of the links connecting the agents belonging to the given community. Participating agents can be defined as the network nodes that connect to other agents through the links, or lines that connect the different points.

This connection can be either directional (where node "A" connects to node "B" but node " $\mathrm{B}$ " does not directly relate to node "A") or bidirectional (where node "A" connects to node "B" and vice versa). Examples of bidirectional networks can be found in family relationships, where all agents relate to each other and, in the case of targeted ones, to the relationships between employers and workers, as illustrated in Figure I (Silva 2015).

Among the various social network methodologies, we highlight the NetMap developed by Eva Schiffer which consists of the elaboration of maps with all the agents belonging to a given group, their relationships, their hierarchy and their objectives. The application of the method is performed, according to Schiffer (2007) and Schiffer and Waale (2008), from an egocentric perspective (the interview is conducted according to the perceptions of an agent or a group of agents) and the agents can be classified according to existing sectors of the economy, and then networks can be subdivided according to the types of existing relationships, being distinguished by the use of different colors in the map design. Interviews are based on a set of semi-structured questions such as: a) "Who is involved?": the intention is to observe all of the agents involved in a given community; b) "How do those involved relate?": this question is fundamental to the identification of the types of relationships existing between the agents involved; c) "What is the degree of influence of each agent?": this demonstrates the degree of influence of each agent belonging to the network; d) "What are the objectives of each agent?": the different objectives that each actor seeks to achieve within the network.

This information is essential to understanding the design of the network and, moreover, is essential to an appreciation of the intrinsic dynamics of existing relationships, their supports, their conflicts, characters that stand out, etc. and, after the interviews, the map is consolidated and then converted into a binary matrix.

The second step in the (re)construction of networks is the inclusion of 
indicators where the map should be transformed into square matrices with the agents arranged in rows and columns and their relationships arranged at the intersections between them. Following the construction of the matrices (it is recommended that they are inputted in Excel format, as this is the most compatible model for later conversions into other software) it is possible to see the network and calculate the indicators that were developed from the Pajek software ${ }^{21}$.

\section{Figure 1. Basic elements of an Interaction Network}

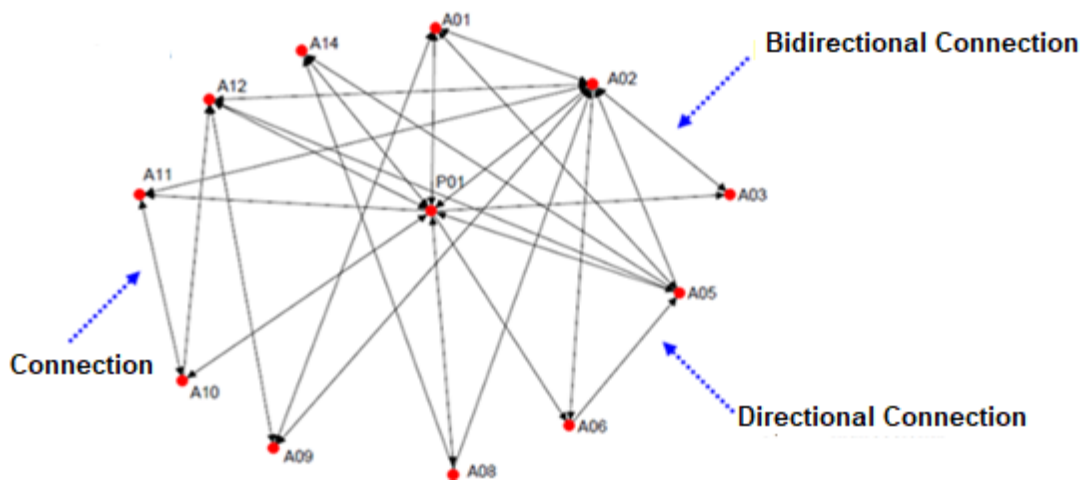

Source: Alejandro and Norman (2005)

According to Nooy et. al. (2005), the network indicators can be subdivided into three categories: cohesion, intermediation and position indicators. In the first criteria, the objective is to investigate cohesion among the agents, i.e., with whom the agents relate, with a focus on behaviors that express an "us" and the degree of those relationships that are present. Next, intermediation indicators measure the capacity of agents to transport information, services or goods, making clear that some individuals occupy central or strategic positions within the network. Finally, position indicators analyze asymmetry between the agents, making clear (through the volume of relations received or sent) the agents who collaborate decisively so that cohesion and bridges with others are formed.

In accordance with this model, the following indicators of cohesion are used: a) Total degree centrality ${ }^{22}$ : calculated through the degree distribution,

2I Software available for download here:<http://mrvar.fdv.uni-lj.si/pajek/>.

22 For the calculation of cohesion indicators, according to Nooy et. al. (2005), the network should be symmetrised, i.e., the direction of relationships (bi- or uni-directional) are not computed. 
which demonstrates the number of agents with which an actor is connected (his/her degree), according to the weight of relationships ${ }^{23}$. This measure makes clear who the central agents are (the most connected) in the network and b) Proximity centrality: the proximity centrality of a vertex is based on the total distance between the vertex and all the others. Greater distances produce smaller proximity centrality scores. The closer a vertex is to all other vertices, the greater its centrality will vary between $\mathrm{O}$ and $\mathrm{I}$.

The degree of intermediation (intermediation indicator) measures the nodes that are "bridge agents", i.e., those that obtain the ability to intermediate relationships between other nodes. This indicator, which also varies between $\mathrm{o}$ and I, measures the capacity that the relationships formed have to create trajectories between them and leverage the development of the network.

Finally, a specific method of measuring the popularity of network agents is calculated to determine the Position (indicator) which displays the centrality of the degree of entry (indegree) of each node, that is, the number of relationships wherein each actor exclusively receives, demonstrating the most popular a within the network.

All indicators were used in the social protection. Org NetMap analysis, however, prior to analysis of the NetMap results, it is important to note that (according to figure 2), the socialprotection.org platform had more than 3,400 members and 800 institutions registered in the platform in June 2018. The platform has organized 69 webinars, has more than roo posts on its blog with more than 3,700 publications that have been shared around the world. In addition, the platform hosts 40 online communities in the area of social protection and maintains thousands of followers on their social networks.

Figure 3 identifies funding sources. The main partners of the platform since its inception have been DFAT, GIZ, DFID, UNICEF and the TRANSFORM inter-agency initiative and more recently, the FAO. The volume of resources invested has grown every year with the exception of a slight decrease in 20I7. Growth was resumed and maintained since, demonstrating the satisfaction of cooperating institutions with the platform and the services provided in the area of international cooperation. It is important to emphasize that a portion of these resources was intended as aid while the rest is invested in projects which the platform will executes through courses and/or other activities.

23 When two agents have more than one type of bond, it is weighted as number 2, while the others are standardized and weighted as I. 
Figure 2. Principal Results of the Platform up until 2018

\section{Main Features and Results}

JUNE 2018
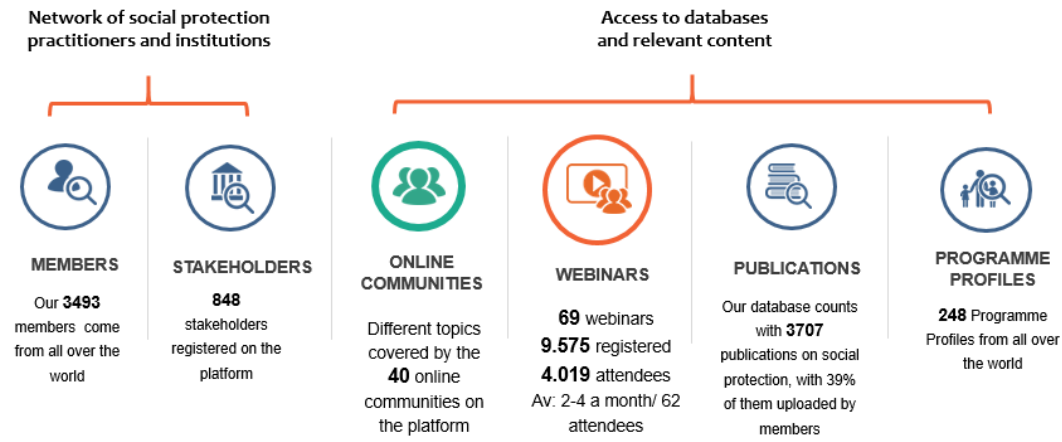

Source: socialprotection.org. GIZ Presentation, 2018

Figure 3. Financial resources received by the socialprotection.org Platform

Financial

resources

\begin{tabular}{|c|c|c|c|c|c|c|c|c|c|}
\hline Partner & Total (USD) & 2014 & 2015 & 2016 & 2017 & 2018 & 2019 & 2020 & 2021 \\
\hline Australian & 901,402 & 156,378 & 156,378 & 156,378 & 216,134 & 216,134 & & & \\
\hline & 265,351 & & & 115,021 & 31,847 & 118,483 & * & * & * \\
\hline 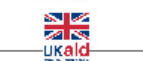 & 50,000 & & 25,000 & 25,000 & & & & & \\
\hline (3) & 46,000 & & 23,000 & 23,000 & & * & & & \\
\hline+1 & 103,056 & & & & 31,528 & $\begin{array}{c}71,528 \\
*\end{array}$ & & & \\
\hline o) & 30,000 & & & & & 30,000 & & & \\
\hline & $1,324,281$ & 156,378 & 204,378 & 319,399 & 279,509 & 436,145 & & & \\
\hline
\end{tabular}

DFAT and GIZ have been the main supporters of the platform's maintenance and development. They have also contributed through knowledge management projects. Other activities have been supported by UNICEF, DFID, FAO and the EU-SPS/OECD

Source: socialprotection.org. GIZ Presentation, 2018.

An interview was conducted with the socialprotection.org platform coordinator in order to initiate the NetMap analysis. The 4 principal thematic questions related to construction of the map (as described in the methodology above) that were included in this interview focused on identifying the principal institutions involved, the types of relationships between them, the intensity of 
those relationships and the objectives of each.

Based on this interview, 22 distinct agents were mapped, each one having a specific and different type of relationships within the platform (Annex I contains a list of the institutions and their acronyms). These agents were categorized as International Organizations, Governmental Institutions, Non-Governmental Organizations (NGOs), Online Projects and Platforms or Consultancies. The following types of relationships were identified:

a) Institutional: Agents that provide institutional support for the platform to operate

b) Financial: Agents that contribute financially to the costs related to the creation, implementation and maintenance of the platform

c) Learning: Agents that have conducted webinars, courses or created online communities using the services of socialprotection.org on more than one occasion content

d) Use: Agents that use the platform as a repository of social protection

It is common that agents maintain more than one type of relationship with socialprotection.org. Double, triple and even quadruple ${ }^{24}$ relationships were identified during this research. The most common were:

e) Dual Relationship: Learning and Use

f) Triple Relationships: Institutional, Learning and Use or Financial, Learning and Use.

Use.

g) Quadruple Relationships: Institutional, Financial, Learning and

Figure 4 displays the network of agents that currently belong to the platform and identifies the most active institutions in the platform. International organizations (II agents) are clearly the most important. The vast majority of these international organizations have at least double relationships with the platform. It is necessary to recognize the difficulty of knowing and understanding all of the relationships that exist between these institutions because agents are active in partnerships, projects and networks beyond the platform. Despite this inherent limitation, it remains worth highlighting the intensity of relations maintained by the IPC-IG, which hosts the platform and (despite being an international body) is the result of a collaboration with the Brazilian government. Inter-agency organizations such as SPIAC-B and TRANSFORM also stand out.

The institutions of German government (GIZ), the English

24 These relationships have weight of 2 in the network 
government (DFID) and, the Australian government (DFAT) were the only ones to have quadruple connections, that is, to achieve all types of existing relations. Specific efforts have been made to attract NGOs, consultancies and other online platforms that, despite their focus on 'Use' and 'Learning' relationships, obtain (according to the platform's coordinator) significant opportunities to enhance their participation in the short and medium term.

An initial analysis of Figure 4 also shows the low level of participation and interest of the Brazilian government in the platform. The map displays exclusively indirect participation because the Brazilian government it is only a part of the agreement to create the IPC-IG platform and to assist with the migration of content developed through the online platform WWP 25 (World Without Poverty) to socialprotection.org, after its end in December 2017. Through observation of the institutions registered on the platform's website, it is possible to find Brazilian institutions such as the MDS, however, there is no record of registered courses and the number of shared publications is much lower than the other institutions included in the map.

According to the platform's coordinator, the platform is global and explicitly avoids focusing its work on particular governments or institutions; all agents are actively encouraged to participate in platform activities. "The use of the platform, although it is described as South-South learning, in practice has a triangular effect on countries, since in most cases it is the international organizations that use the platform as a source of inspiration for new projects" (Interview with socialprotection.org coordinator).

Figure 4. NetMap of the Main Institutions Participating in the socialprotection.org Platform

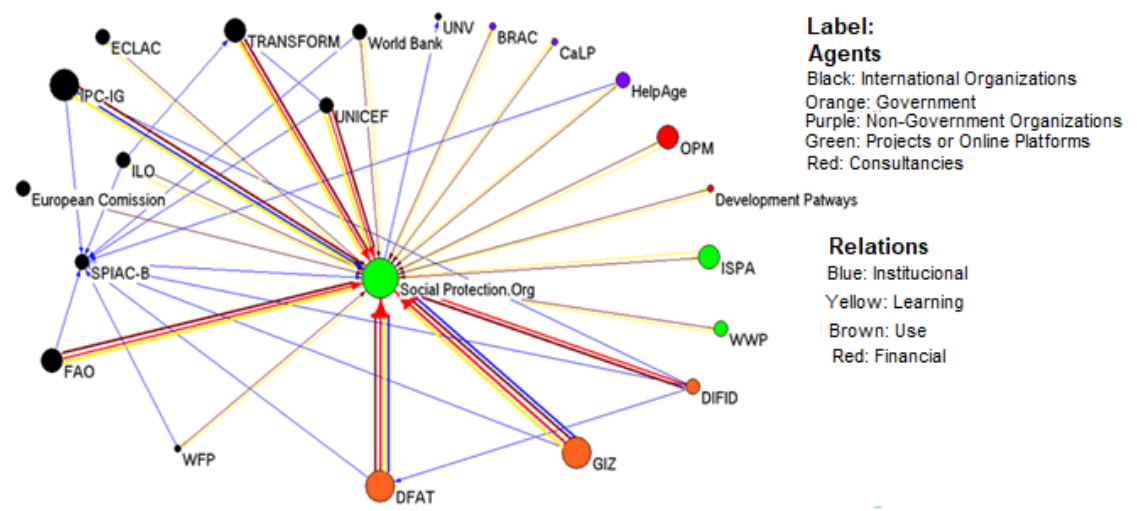

Source: Field research 
Another relevant factor that can be observed in Figure 4 is the size of the nodes of each agent, representing the degree of influence. As highlighted in the methodology, this ranking ranges from o to 5 and, according to Graph I, the most influential agents are precisely those that provide institutional and financial support including the IPC-IG, DFID, DFAT and GIZ. On the other hand, UNV, WFP and consultancies such as Development Pathways, BRAC and CaLP maintain a strong influence and a high level of participation, indicating that there is room to grow their contributions.

The objectives of the actors follow the definitions articulated in the typologies of relationships. Most of them aim to use the platform for sharing of publications and programs ('Use') and 'Learning' through conducting and participating in webinars, courses and online communities. Only GIZ, DFAT and DFID stand out for having multiple objectives; both 'Institutional' and 'Use'. It is important to mention that no conflicts were detected in this network, which indicates that there is more space to add new members and increase the sharing of information.

\section{Graph 1. Influence Ranking of the Network Agents of the socialprotection.org platform}

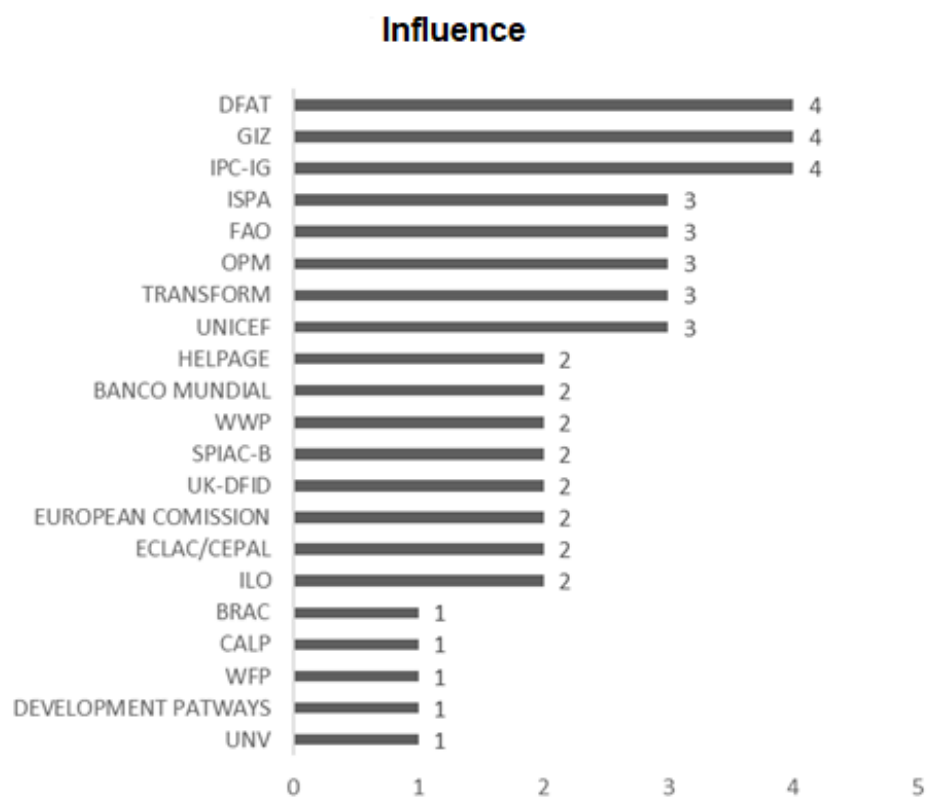

\section{Source: Field research.}


Observing the Cohesion indicators, the degree of network centrality demonstrates that, on average, each agent obtains close to 3.I8 connections and, as expected, socialprotection.org has the highest number (with 2I connections). Among the actors with the lowest number of connections was the UNV and the European Commission. SPIAC-B stands out with II connections and a value of 0.68 for degree of centrality, which is expected since it is an international inter-agency body that maintains several simultaneous connections between different institutions. The other agents are within the average for the number of relationships and obtain values for degree of centrality of between 0.50 and 0.60 , mainly due to the difficulty in obtaining information about existing relationships between international organizations since they coordinate and participate in numerous projects and maintain a broad diversity of bi and multilateral partnerships.

Proximity centrality values measure the 'closeness' of agents the network. Actors such as SPIAC-B (o.67), IPC-IG, FAO, GIZ, DFID and DFAT between 0.53 and 0.60 all stand out for having high values centrality values. This indicates that they all have the capacity to enter into relations with the others and that there are no isolated actors in the network. Analyzing the degree of intermediation, it is noted that the capacity to intermediate relations is 0.88 and, with I being the maximum value, the capacity of these agents to intermediate relations is very high.

Finally, when considering the popularity of the agents, as illustrated in Graph 2, it is clear that after removing the platform itself and SPIAC-B, all the other agents are within the average (3.I8 connections), which shows, on the one hand, openness to new connections between these agents (mainly because they already participate in an online platform for sharing information) and, on the other, the inability to identify all the relationships involved by the various international agencies, due to their extensity.

Since the creation of the platform, the ranking of influence and the cohesion, intermediation and position indicators, one conclusion is clear: participation of the Brazilian government agencies in the network led to connections to the most influential actors through the IPC-IG and the WWP and only indirectly to the government itself. Thus, the federal Brazilian government and the agencies linked to the Ministry of Foreign Affairs (MRE) such as the ABC, lost the opportunity to connect to platform agents focused on social protection and South-South learning that are inserted internationally. 


\section{Graph 2. Popularity of the socialprotection.org platform agents}

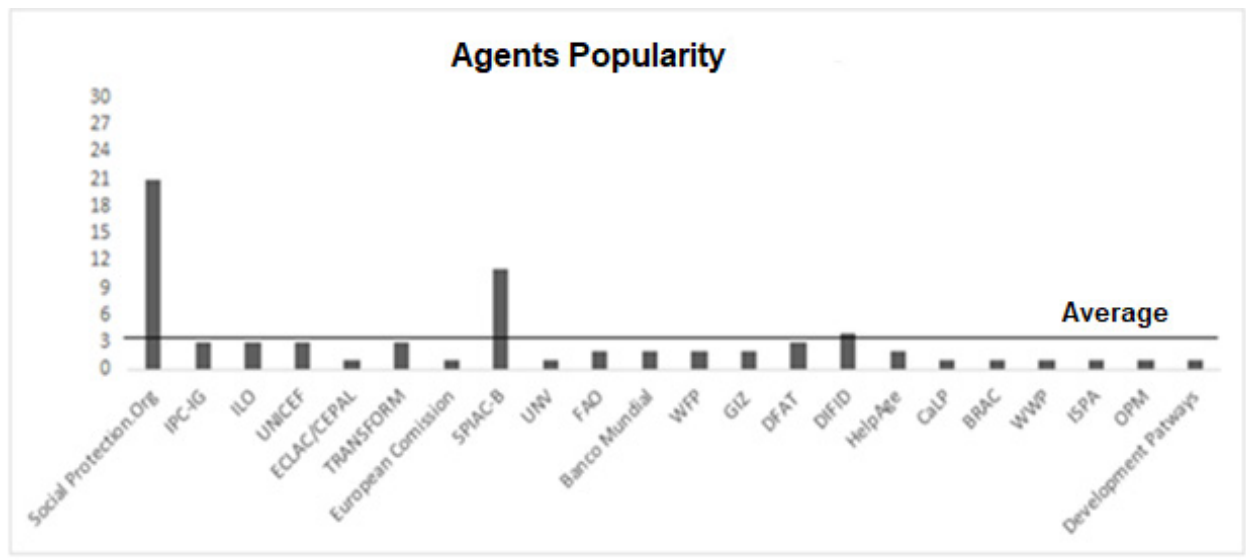

\section{Source: Field research}

Consequently, any reduction or crisis in Brazilian SSC will not directly affect the platform, since there are few existing direct connections. Thus, the hypothesis that the decrease in public spending on social policy compromises SSC using the socialprotection.org platform as a representative proxy is not fully confirmed since before the crisis that began shortly after 20I6, the Brazilian government no longer had strong participation in the platform. Regardless of the platform, the Brazilian SSC crisis already shows strong signs of having started in $201 \mathrm{II}$ and, according to the evidence gathered, the current crisis will only deepen what was already a tendency.

The difficulty in solidifying the links between platform agents, including the excessive focus on specific social protection programs in Brazil, such as the Bolsa Família, makes knowledge in the area less widespread and hinders communication and experience exchanges, exactly the opposite of what is advocated by ICD and SSC objectives which should be included in future government plans.

\section{Final Remarks}

Brazilian foreign policy has historically taken the form of insertion based on trade and peaceful actions. Since the end of the Second World War, the international system has become more multilateral and, with the support 
of the United Nations, ICD and SSC, particularly in South America stand out as mechanisms for sharing experiences, projects, and knowledge between emerging countries, particularly between middle-income and low-income countries.

Efforts made between 2005 and 2009 to promote ICD and SSC by increasing the volume of resources applied in this area six-fold, was essential to the implementation of a series of agreements, research centers and projects in Latin American, African and Caribbean countries. The importance of partnerships with the United Nations, both UNDP and FAO after 2004 were of special importance. The first center of research excellence, the IPC-IG, was founded in 2004 and since then has provided a global forum for South-South dialogue on innovative development policies while seeking to produce and disseminate projects, policies and exchanges of best practices.

Among the various activities carried out by the Centre, the creation of the social protection.org platform emerged as a specific recommendation of the G2O Development Group. Since its launch in 2015 this platform has been a repository of learning resources on social protection, with a specific interest in South-South learning. The execution of this research included interviews with senior coordinators of the IPC-IG, the coordinator of the platform and the current founder of the consultancy firm Development Pathways (an exDIFID official).

According to the historical network analysis, the collaboration of the Brazilian government since the launch of the Centre is clear. However, its initial intention was not to be an organ aimed at building South-South learning tools. This change occurred gradually and resulted from the lack of technical capacity and resources of the Brazilian government itself to meet international demand and its excessive focus on the Bolsa Familia program. The gradual steps towards the crisis that was evident in 2016 began in 201 , when the relative deceleration of the volume of resources dedicated to ICD and SSC began.

The socialprotection.org platform, hosted by IPC-IG, has proved its global utility and has continuously increased the number of members, institutions and online communities over the years. The most prominent institutions and international organizations that are the main collaborators are government institutions principally those from Germany, Australia and England. Brazilian government participation has always been indirect and marginal, demonstrating that has consistently missed the opportunity to actively participate in an international online platform. This is a situation that will most likely worsen coming years. Importantly, this indirect and marginal connectivity means that any deepening of the crisis in Brazilian ICD and SSC 
will not compromise the continued work of the platform.

Clearly, the current crisis in ICD and SSC did not begin in 2016. ICD and SSC as policies and strategies for international cooperation were losing priority and focus as early as 20II. The current scenario clearly presents a recipe for a deepening of this ongoing crisis (due to the cuts institutionalized with constitutional amendment (EC) 95 and the explicitly neoliberal government plan known as "A Bridge to the Future"). Despite these immediate, near term difficulties, it is expected that future governments will modify this position and that they will return to the alliances that have been consolidated over decades, particularly those with the United Nations and its diverse departments and agencies.

\section{ANNEX}

\begin{tabular}{|c|c|}
\hline Acronyms & Institutions \\
\hline IPC-IG & $\begin{array}{l}\text { International Policy Centre for Inclusive } \\
\text { Growth }\end{array}$ \\
\hline ILO & International Labour Organization \\
\hline UNICEF & United Nations Children's Fund \\
\hline ECLAC/CEPAL & $\begin{array}{l}\text { United Nations Economic Commission } \\
\text { for Latin America and the Caribbean }\end{array}$ \\
\hline TRANSFORM & $\begin{array}{l}\text { Leadership \& } \& \text { Transformation } \\
\text { Curriculum on Building and Managing } \\
\text { Social Protection Floors in Africa }\end{array}$ \\
\hline EC & European Comission \\
\hline SPIAC-B & $\begin{array}{l}\text { Social Protection } \\
\text { Cooperation Board }\end{array}$ \\
\hline UNV & The United Nations Volunteers \\
\hline FAO & $\begin{array}{l}\text { Food and Agriculture Organization of } \\
\text { the United Nations }\end{array}$ \\
\hline WB & World Bank \\
\hline WFP & World Food Programme \\
\hline GIZ & $\begin{array}{lrr}\text { Deutsche } \quad \text { Gesellschaft } & \text { für } \\
\text { Internationale Zusammenarbeit } & \\
\end{array}$ \\
\hline DFAT & $\begin{array}{l}\text { Australia - Department of Foreign } \\
\text { Affairs and Trade }\end{array}$ \\
\hline DFID & $\begin{array}{l}\text { UK- Department for International } \\
\text { Development }\end{array}$ \\
\hline
\end{tabular}




\begin{tabular}{|l|l|}
\hline HelpAge & HelpAge International \\
\hline CaLP & Cash Learning Partnership \\
\hline BRAC & $\begin{array}{l}\text { International Development Organization } \\
\text { based in Bangladesh }\end{array}$ \\
\hline WWP & World Without Poverty \\
\hline ISPA & $\begin{array}{l}\text { Inter Agency Social Protection } \\
\text { Assessments }\end{array}$ \\
\hline socialprotection.org & socialprotection.org \\
\hline OPM & Oxford Policy Managment \\
\hline Development Pathways & Development Pathways \\
\hline
\end{tabular}

\section{REFERENCES}

Alejandro, Velásquez Alzvaréz; Norman, Aguillar Gallegos. 2005. Manual introdutório à análise de redes sociais: Medidas de centralidade, pp. I-I6.

Amorim, Celso. 2007. "A diplomacia multilateral do Brasil: Um tributo a Rui Barbosa." In: Palestra do Ministro das Relações Exteriores na II Conferência Nacional de Política Externa e Política Internacional - O Brasil e o Mundo que vem aí. Fundação Alexandre de Gusmão, Rio de Janeiro, Palácio Itamaraty, pp. 3-24.

Barros, Ricardo Paes de; Henriques, Ricardo; Mendonça, Rosane. 2000. "A estabilidade inaceitável: desigualdade e pobreza no Brasil". In: Ricardo Henriques (Org.). Desigualdade e Pobreza no Brasil. I ed. Brasília: Instituto de Pesquisa Econômica Aplicada - IPEA, p. I-47.

Barros, Ricardo Paes de; Carvalho, Mirela de; Franco, Samuel; Mendonça, Rosane. 2007. "A queda recente da desigualdade de renda no Brasil". In: Barros, R. P., Foguel, N., Ulysses, G. (org) Desigualdade de Renda no Brasil: uma análise da queda recente (parte1). Rio de Janeiro: IPEA, p. I07-I27.

Blatter, Joachim; Haverland, Markus. 20I2. "Designing Case Studies: Exploratory Approach in Small-N Studies". In: Research Methods Series. ECPR. 2012.

Chediek, Jorge. 20I7. "O papel do Brasil na cooperação sul-sul: Um estudo analítico e histórico". In: Almino, João; Lima, Sérgio Eduardo Moreira (Orgs). 30 Anos da ABC: Visões da cooperação técnica internacional brasileira. Fundação Alexandre Gusmão, Brasília, pp. 4I-74. 
Fraundorfer, Markus. 20I2. "Fome Zero para o Mundo - A Difusão Global Brasileira do Programa Fome Zero". In: Revista Brasileira de Estratégia e Relações Internacionais, v.2, n. 4, pp. 97-I22.

Guimara es, Samuel Pinheiro. 2013. O imperialismo, o sistema internacional e o Brasil: Reflexões sobre a política internacional. São Paulo: Editora Fundação Perseu Abramo, I44p.

Hirst, M. 20I2. "Aspectos Conceituais e Práticos da Atuação do Brasil em Cooperação Sul-Sul: Os Casos de Haiti, Bolívia e Guiné Bissau”. In: Texto para Discussão $n^{\circ}$ 1687. Instituto de Pesquisa Econômica Aplicada, Rio de janeiro, janeiro de 2012.

Instituto Brasileiro de Geografia e Estatística (IBGE). 20I7. "Síntese de Indicadores Sociais: Uma Análise das Condições de Vida da População Brasileira". Brasília: Estudos e Pesquisas, n 38 .

Instituto de Pesquisa Econômica Aplicada (IPEA); Agência Brasileira de Cooperação (ABC). 20IO. Cooperação brasileira para o desenvolvimento internacional: 2005-2009. Brasília, 78 p.

Instituto de Pesquisa Econômica Aplicada (IPEA); Agência Brasileira de Cooperação (ABC). 20I6. Cooperação brasileira para o desenvolvimento internacional: 2011-2013. Brasília, I84 p.

Johnson, Erik C.; Khalid, Ramla. 2005. "Communities of Practice for Development in the Middle East and North Africa”. In: KM4D Journal 1(1), pp. 96-IIo.

Leite, Iara Costa; Suyama, Bianca; Waisbich, Laura Trajber. 2013. "Para além do tecnicismo: a Cooperação Brasileira para o Desenvolvimento Internacional e caminhos para sua efetividade e democratização". In: Policy Brief. Articulação Sul, CEBRAP, Institute of Development Studies, pp. I-6.

Leite, Iara Costa; Suyama, Bianca; Waisbich, Laura Trajber; Pomeroy; Melissa; Constantine, Jennifer; Navas-Alemán, Lizbeth; Shankland, Alex; Younis, Musab. (20I4). Brazil's Engagement in International Development Cooperation: The State of the Debate. Institute of Development Studies. I03 p.

Kidd, Stephen; Huda, Karishma. (20I3). "BOLSA unFAMILIAr". In: PATHWAYS' PERSPECTIVES on social policy in international development. Issue number o9, United Kingdom, pp. I-II.

Milani, Carlos R. 20I2. "Aprendendo com a história: Críticas à experiência da Cooperação Norte-Sul e atuais desafios à Cooperação Sul-Sul." In: Caderno CRH, vol. 25, núm. 65. Universidade Federal da Bahia, Salvador, pp. 2II-23I. 
Nooy, Wounter; Mrvar, Andrej; Batagelj, Vladimir. 2005. "Exploratory Social Networks with Pajek". In: Structural Analysisin the Social Sciences. Cambridge Press, $200 \mathrm{p}$.

Osório, Rafael. 20I5. "Desigualdade e Pobreza". In: Calixtre, André; Vaz, Fábio. PNAD 2014 - Breves Análises. Nota Técnica do Instituto de Pesquisa Econômica Aplicada (IPEA), Brasília, nº 22, p. 3-7.

Pecequilo, Cristina Soreanu. 20I2. "O Brasil e os eixos periféricos: agenda e identidade nas relações internacionais". In: Cadernos de Estudos Culturais, vol. 4, pp. 25-38.

Pecequilo, Cristina Soreanu. 2008. "A Política Externa do Brasil no Século XXI: Os Eixos Combinados de Cooperação Horizontal e Vertical”. In: Revista Brasileira de Política Internacional, n. 5I, v.2, pp. I36-I53.

Rossi, Pedro. 20I5. "Regime Macroeconômico e o Projeto SocialDesenvolvimentista," Texto para Discussão 2029. Brasília, Instituto de Pesquisa Econômica Aplicada (IPEA), p. I-48.

Schiffer, Eva. 2007. "Manual NetMap toolbox". International Food Policy Research Institute. 2007, pp. I-30.

Schiffer, Eva; Waale, David. 2008. "Tracing power and influence networks: NetMap as a tool for research ans strategic network planning”. In: IFPRI Discussion Paper 00772.

Silva, Patrícia Andrade de Oliveira e; Almeida Filho, Niemeyer. 2019. "Cooperação Internacional para o Desenvolvimento: O Caso Brasileiro". In: II Conferencia sobre planificación del desarrollo "Julio H. G. Olivera”, Buenos Aires, Argentina, 20I9 (presentation).

Silva, Patricia Andrade de Oliveira e. 20I7. "Social Policy in Brazil (200420I4): An overview”, Policy in Focus. Working Paper $n^{\circ}$ 155, Brasília, pp. I-24.

Silva, Patricia Andrade de Oliveira e. 20I5. "Capital Social e Políticas de Combate à Pobreza no Brasil: Uma Análise em Redes”. Tese de Doutorado em Desenvolvimento Econômico, Espaço e Meio Ambiente. Universidade Estadual de Campinas. Campinas..

Soares, Fábio Veras; Soares, Serguei; Medeiros, Marcelo; Osório, Rafael Guerreiro. 2006. "Cash Transfer Programmes in Brazil: Impacts on Inequality and Poverty". In: International Poverty Centre, Working Paper 21, Brasília.

Soares, Fábio Veras; Ribas, Rafael Perez; Osório, Rafael Guerreiro. 2007. "Evaluating the Impact of Brazil's Bolsa Família: Cash Transfer Programmes in Comparative Perspective." In: International Poverty 
Centre: IPC Evaluation Note, number I, Brasília, pp. I-I4.

Soares, Serguei; Osório, Rafael Guerreiro; Soares, Fábio Veras; Medeiros, Marcelo; Zeped, Eduardo. 2007. "Programas de Transferência Condicionada de Renda no Brasil, Chile e México: Impactos Sobre a Desigualdade." In: Instituto de Pesquisa Econômica Aplicada (IPEA). Texto para Discussão no 1293. Brasília, pp. I-3I.

Social Protection.org. 20I6. "Annual Report: 20I6”, Brasília, pp. I-47.

Social Protection.org.. 20I7. "Annual Report: 20I7”, Brasília, pp. I-6o.

Social Protection.org. . 20I8. “Overview Activites”. In: GIZ Presentation, July/ August.

Ulhôa, Wander Marcondes Moreira; Almeida Filho, Niemeyer. 20I8. "Estado e Políticas Públicas sob o "Novo Regime Fiscal"”. In: Anais do XXIII Encontro Nacional de Economia Política. Niterói: Universidade Federal Fluminense.

United Nations (ONU). (2009). Report of the High-level United Nations Conference on South-South Cooperation. General Assembly, Nairobi, I-3 December, pp. I-23.

\section{ABSTRACT}

The current Brazilian political and economic context is one of intense crisis and it will inevitably impact public policies. In 2000's, practices of International Cooperation and Development (ICD) gained emphasis through organized experience sharing between developing country governments and international organizations. Brazil deepened its partnerships with others Southern countries, a practice that came to be known as South-South Cooperation (SSC). However, following the impeachment of President Dilma Rousseff in 20I6, the incoming administration introduced government spending limits in the form of a Constitutional Amendment (95/2016) which structurally decreased resources available for SSC and consequently limited possibilities to continue deepening international involvement. This article analyzes the first effects of the new fiscal regime for SSC using a bibliographic review and a case study of the Social Protection.Org platform which is managed by the International Policy Centre for Inclusive Growth (IPC-IG), a centre of research excellence established through a partnership between the United Nations and Brazilian government.

\section{KEYWORDS}

South-South Cooperation; Brazilian Fiscal Regime; Brazilian Crisis.

Received on December 3, 2019 Approved on May 8, 2020 